\title{
Medical student perspectives on the application of social media in higher education [Response to Letter]
}

This article was published in the following Dove Press journal: Psychology Research and Behavior Management

\author{
Salman Yousuf Guraya' \\ Mona Faisal Al-Qahtani ${ }^{2}$ \\ B Bilal $^{3}$ \\ Shaista Salman Guraya ${ }^{4}$ \\ Hamdi Almaramhy ${ }^{5}$ \\ 'Surgery Unit, Clinical Sciences \\ Department, College of Medicine, \\ University of Sharjah, Sharjah, UAE; \\ ${ }^{2}$ Department of Public Health, College of \\ Public Health, Imam Abdulrahman Bin \\ Faisal University, Dammam, Saudi Arabia; \\ ${ }^{3}$ School of Accountancy, Hubei University \\ of Economics, Wuhan, People's Republic \\ of China; ${ }^{4}$ Medical Education Unit, \\ College of Medicine, University of \\ Sharjah, Sharjah, United Arab Emirates; \\ ${ }^{5}$ Pediatric Surgery, College of Medicine, \\ Taibah University Almadinah \\ Almunawwarah, Medina, Saudi Arabia
}

Correspondence: Salman Yousuf Guraya

Surgery Unit, Clinical Sciences

Department, College of Medicine,

University of Sharjah, Building M-27 PO

Box 27272, Sharjah, UAE

Email salmanguraya@gmail.com

\section{Dear editor}

We are glad to respond to the letter to the editor and acknowledge the interest of the readers in my publication.

As literature has rightly signaled an escalating rise in the use of social networking sites (SNSs) for social interactions, information exchange, fun, and leisure, there is a disproportionate rise in SNSs usage by university students for education. A meta-analysis has shown that although approximately $75 \%$ of the medical and health science students used SNSs for several purposes, only $20 \%$ of them used SNSs for education. ${ }^{1}$ This study strongly stressed the need to incorporate SNSs in all instructional strategies of the medical curricula along with rigorous training of the students and academics. Probing the educational use of SNSs by the medical students, another study used the validated inventory of Social networking Sites in Medical Education and estimated the extent and nature of the use of SNSs. ${ }^{2}$ This study reported that though $1181(90 \%)$ students used SNSs, only 442/1181 $(37 \%, p<0.00)$ students used SNSs for education. Interestingly, a great majority of those respondents who used SNSs for education strongly recommended the incorporation of social media in curriculum for high academic performance, peerassisted learning opportunities, and interactive reciprocal learning climate.

The concern raised by the author of letter to the editor about sensitive issues of privacy and confidentiality need attention. As detailed in my article, injudicious use of SNSs by university students is never recommended as such usage will end up with breach in confidentiality and violation of societal norms and cultural boundaries. ${ }^{3}$ As we know that the students are increasingly involved in e-learning platforms that are developed and powered by institutional support. However, all such platforms would be redundant and disabled for the students after their graduation. Consequently, they will be leaning toward other digital platforms such as SNSs for further education and connectivity. Furthermore, there is a great surge toward virtual learning across the globe and this climate can only be accomplished through sustainable digital platforms. Lastly, the impact of SNSs has been advocated by 3 Ps; permanent, powerful, and public. ${ }^{4}$ Consequently, using SNSs during undergraduate, postgraduate studies, and professional service will lead to life-long and permanent conventions.

The value of SNSs can only be recognized when academics and all other stakeholders are trained by well-structured faculty and students' development programs. ${ }^{5}$ These training programs target enhancement of skills and knowledge of new courses 
and instructional strategies. Our study advocate incorporation of SNSs for education. However, as stressed in the article, a careful use of social media should be employed under regulations by The Governance of Social Media, The Digital Millennium Copyright Act, and the Framework for Intellectual Property by global Internet fraternity. ${ }^{6}$ Both the use of SNSs and its regulatory framework should be implemented simultaneously by institutional administrators.

\section{Disclosure}

The authors report no conflicts of interest in this communication.

\section{References}

1. Guraya SY. The usage of social networking sites by medical students for educational purposes: a meta-analysis and systematic review. $N \mathrm{Am}$ J Med Sci. 2016;8(7):268. doi:10.4103/1947-2714.187131
2. Guraya SY, Almaramhy H, Al-Qahtani MF, Guraya SS, Bouhaimed M, Bilal B. Measuring the extent and nature of use of Social Networking Sites in Medical Education (SNSME) by university students: results of a multi-center study. Med Educ Online. 2018;23(1):1505400. doi:10.1080/ 10872981.2018 .1505400

3. Guraya SY, Al-Qahtani MF, Bilal B, Guraya SS, Almaramhy H. Comparing the extent and pattern of use of social networking sites by medical and non medical university students: a multi-center study. Psychol Res Behav Manag. 2019;12:575-584. doi:10.2147/PRBM. S204389

4. Klimmt C, Hefner D, Reinecke L, Rieger D, Vorderer P. The Permanently Online and Permanently Connected Mind: Mapping the Cognitive Structures behind Mobile Internet Use. InPermanently Online, Permanently Connected. Routledge; 2017 July $28: 32-42$

5. Guraya SY, Chen S. The impact and effectiveness of faculty development program in fostering the faculty's knowledge, skills, and professional competence: a systematic review and meta-analysis. Saudi J Biol Sci. 2017.

6. Obar JA, Wildman SS. Social media definition and the governance challenge-an introduction to the special issue. Telecomm Policy. 2015;39(9):745-750. doi:10.1016/j.telpol.2015.07.014

Dove Medical Press encourages responsible, free and frank academic debate. The content of the Psychology Research and Behavior Management 'letters to the editor' section does not necessarily represent the views of Dove Medical Press, its officers, agents, employees, related entities or the Psychology Research and Behavior Management editors. While al reasonable steps have been taken to confirm the content of each letter, Dove Medical Press accepts no liability in respect of the content of any letter, nor is it responsible for the content and accuracy of any letter to the editor.

\section{Publish your work in this journal}

Psychology Research and Behavior Management is an international, peer-reviewed, open access journal focusing on the science of psychology and its application in behavior management to develop improved outcomes in the clinical, educational, sports and business arenas. Specific topics covered in the journal include: Neuroscience, memory and decision making; Behavior modification and management; Clinical applications; Business and sports performance management; Social and developmental studies; Animal studies. The manuscript management system is completely online and includes a very quick and fair peer-review system, which is all easy to use. Visit http://www. dovepress.com/testimonials.php to read real quotes from published authors. 